\title{
Draft genome sequence of Bacillus pumilus strain EZ-C07 isolated from digested agricultural wastes
}

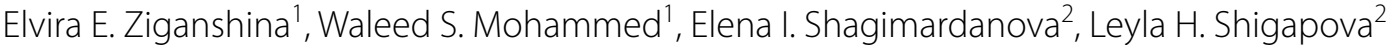 \\ and Ayrat M. Ziganshin ${ }^{1 *}$ (D)
}

\begin{abstract}
Objectives: Bacillus species, belonging to the family Bacillaceae, are rod-shaped aerobic or facultative anaerobic Gram-positive bacteria that can be isolated from various environmental niches. Bacillus pumilus strains are resistant to unfavorable conditions such as $\mathrm{UV}, \mathrm{H}_{2} \mathrm{O}_{2}$ and chemical disinfection. Furthermore, B. pumilus strains synthesize multifarious important enzymes and can be used in the production of some fermented foods, bioremediation of wastewater systems and biodegradation of environmental contaminants. Hence, investigation at the genomic level is required to understand their ecology, genetics and potential applications.
\end{abstract}

Data description: In this research, we provide the genomic insights into one Bacillus species (EZ-C07) isolated from digested agricultural waste materials. The draft genome of the strain EZ-C07 consists of 3,724,869 bp with 3890 coding sequences and $41.5 \% \mathrm{G}+\mathrm{C}$ content. Based on $16 \mathrm{~S}$ rRNA gene sequence analysis followed by in silico DNA-DNA hybridization studies, the strain EZ-C07 was identified as Bacillus pumilus belonging to the family Bacillaceae within the phylum Firmicutes. The whole genome shotgun project of B. pumilus strain EZ-C07 can be accessed at DDBJ/ENA/ GenBank under the Accession QLVI00000000.

Keywords: Poultry manure, Bioreactor, Genome sequencing, Firmicutes, Bacillus pumilus

\section{Objective}

Bacillus species, belonging to the family Bacillaceae, are rod-shaped aerobic or facultative anaerobic Gram-positive bacteria that can be isolated from various environments. One of the features of this genus is the ability to form endospores in response to various environmental and nutritional stresses $[1,2]$. 16S rRNA gene sequence analysis showed a high level of phylogenetic heterogeneity in the genus Bacillus. Members of this genus can produce a wide range of useful pharmaceutical, agricultural and industrial products (such as antibiotics, enzymes, amino acids, sugars) [1-3]. Also, several Bacillus strains with strong proteolytic activities displayed the robust

\footnotetext{
*Correspondence: ayrat.ziganshin@kpfu.ru

${ }^{1}$ Department of Microbiology, Institute of Fundamental Medicine

and Biology, Kazan (Volga Region) Federal University, Kremlyovskaya str.

18, Kazan 420008, Russia

Full list of author information is available at the end of the article
}

survival in the protein-fed anaerobic biogas reactors and finally improved the biogas productivity [4]. The anaerobic digestion of biomass belongs to a more suitable method to utilize various agricultural waste materials [5, 6].

From the array of various Bacillus species, Bacillus pumilus strains are resistant to unfavorable conditions, including $\mathrm{UV}, \mathrm{H}_{2} \mathrm{O}_{2}$ and chemical disinfection $[7,8]$. In addition, based on their abilities to synthesize multifarious enzymes and several other bioactive compounds [9, 10], B. pumilus strains can be used in fermented foods production [11], biofertilizers synthesis [12], bioremediation of wastewater systems [13] and biodegradation of environmental contaminants [14]. Moreover, some $B$. pumilus strains were previously isolated from a biogas reactor utilizing abattoir waste [15]. Hence, more investigations at the genomic level are required to understand ecology, genetics and potential applications of B. pumilus 
Table 1 Overview of data files/data sets

\begin{tabular}{llll}
\hline Label & Name of data file/data set & File types (file extension) & $\begin{array}{l}\text { Data repository and identifier (DOI } \\
\text { or Accession Number) }\end{array}$ \\
\hline Data file 1 & Whole genome shotgun project & FASTA & $\begin{array}{l}\text { DDBJ/ENA/GenBank (Accession QLVI000000000) } \\
\text { GenBank (Accession MH510687) }\end{array}$ \\
\hline Data file 2 & 16S rRNA gene sequence & FASTA & GenBar \\
\hline
\end{tabular}

strains in different biotechnologies. The search of various useful bacterial strains is a thrust area in biotechnological research and their implications to produce various compounds.

\section{Data description}

Bacillus pumilus strain EZ-C07 was isolated from the effluent of a biogas reactor fed with agricultural wastes, including chicken manure, and operated at high ammonia levels $\left(>4.0 \mathrm{NH}_{4}-\mathrm{Ng} \mathrm{L}^{-1}\right)$. The chicken manure was obtained from a poultry farm located in the Zelenodolsky district, the Republic of Tatarstan (Russian Federation). The bacterial strain B. pumilus EZ-C07 was cultured on Luria-Bertani agar at $+37{ }^{\circ} \mathrm{C}$ for $24-48 \mathrm{~h}$ under microaerophilic conditions. Genomic DNA extraction and preparation for further sequencing were performed as described previously [16]. Briefly, genomic DNA of the strain EZ-C07 was isolated by using a FastDNA spin kit (\#116540600; MP Biomedicals, USA) and a FastPrep-24 homogenizer (\#116004500; MP Biomedicals, USA). Extracted DNA quality was estimated by agarose gel electrophoresis, while concentration and purity of the received DNA were estimated with a NanoDrop 2000 spectrophotometer (\#ND-2000; Thermo Fisher Scientific, USA). Extracted DNA sample of the strain was stored at $-20{ }^{\circ} \mathrm{C}$ until further processing. The identification of the strain B. pumilus EZ-C07 was based on morphological characteristics and biochemical tests and then confirmed by sequencing of its $16 \mathrm{~S}$ rRNA gene (Accession Number MH510687) on an ABI PRISM 3130xl Genetic Analyzer (\#4359571; Thermo Fisher Scientific, USA) (Table 1).

To perform genome sequencing, DNA was fragmented with a Q800R2 DNA Shearing Sonicator (\#Q800R2-110; Qsonica, USA), and DNA library preparation was fulfilled with a NEBNext Ultra DNA Library Prep Kit for Illumina (\#E7370S; New England Biolabs Inc., USA). Effectiveness of DNA fragmentation and preparation of DNA library was analyzed with a 2100 Bioanalyzer Instrument (\#G2939BA; Agilent Technologies, USA). The bacterial genome of $B$. pumilus EZ-C07 was sequenced by a HiSeq 2500 Sequencing System (SY-401-2501; Illumina, USA), HiSeq PE Rapid Cluster Kit v2 (PE-4024002; Illumina, USA) and HiSeq Rapid SBS Kit v2 (500 cycles) (FC-402-4023; Illumina, USA). Sequence quality of the genome was analyzed with FastQC software version 0.11.7. The genome was then assembled with Velvet version 1.2.10 [17], and the received contigs were ordered with Mauve version 2.4.0 [18] with default parameters. The genome sequence of $B$. pumilus EZ-C07 was annotated with the RAST automatic annotation server [19]. The rRNA and tRNA genes were determined with the RNAmmer 1.2 server [20] and tRNA scan-SE 1.23 search server [21], accordingly. Finally, based on $16 \mathrm{~S}$ rRNA gene sequence analysis followed by in silico DNA-DNA hybridization studies (against type strain $B$. pumilus ATCC 7061), the strain was identified as Bacillus pumilus belonging to family Bacillaceae within the phylum Firmicutes.

The obtained genome sequence of $B$. pumilus EZ-C07 included 31 contigs ( $>500 \mathrm{bp}$ in size) with a calculated size of $3,724,869 \mathrm{bp}$ in length and N50 of 183,828 bp. The $\mathrm{G}+\mathrm{C}$ content for the draft genome is $41.5 \%$. A total of 3890 coding sequences (CDS) were predicted, where 1818 CDS (47\%) were annotated as seed subsystem features and 2072 CDS (53\%) were annotated as outside of the seed subsystem. In total, 2675 and 1215 proteins were identified as non-hypothetical and hypothetical, respectively. It was demonstrated that genome encoded at least 3 rRNAs and 50 tRNAs. The strain B. pumilus EZ-C07 possesses numerous genes involved in monosaccharides and proteins metabolism, fermentation, as well as biphenyl and gentisate biodegradation. Many genes responsible for the bacterial strain resistance to several antibiotics and various toxic compounds, such as arsenic, cobalt, zinc and cadmium, were also identified. This resistant bacterial strain can be used in different biotechnologies.

\section{Limitations}

The obtained results are based on the draft genome assembly; therefore, the exact genome's length, number of rRNAs, repetitive elements cannot be certainly reported. Also, the presence of any plasmids cannot be clearly predicted.

\section{Authors' contributions}

EEZ and WSM carried out experiments, performed interpretation of the received data and drafted the manuscript. EIS and LHS carried out Illumina HiSeq sequencing and revised the manuscript. AMZ supervised the project, performed genome analysis and professionally revised the manuscript. All authors read and approved the final manuscript. 


\section{Author details}

1 Department of Microbiology, Institute of Fundamental Medicine and Biology, Kazan (Volga Region) Federal University, Kremlyovskaya str. 18, Kazan 420008 , Russia. ${ }^{2}$ Laboratory of Extreme Biology, Institute of Fundamental Medicine and Biology, Kazan (Volga Region) Federal University, Kazan 420021, Russia.

\section{Acknowledgements}

Not applicable.

\section{Competing interests}

The authors declared that they no competing interests.

\section{Availability of data materials}

The data described in this Data note can be freely and openly accessed at DDBJ/ENA/GenBank. Accession Numbers-QLVI00000000 (whole genome shotgun project) and MH510687 (16S rRNA gene sequence).

\section{Consent for publication}

Not applicable.

\section{Ethics approval and consent to participate}

Not applicable.

\section{Funding}

The reported study was funded by the Russian Foundation for Basic Research [Grant No. 16-34-60093 mol_a_dk].

\section{Publisher's Note}

Springer Nature remains neutral with regard to jurisdictional claims in published maps and institutional affiliations.

Received: 9 July 2018 Accepted: 14 August 2018

Published online: 22 August 2018

\section{References}

1. Lyngwi NA, Joshi SR. Economically important Bacillus and related genera: a mini review. In: Sen A, editor. Biology of useful plants and microbes. New Delhi: Narosa Publishing House; 2014. p. 33-43.

2. Checinska A, Paszczynski A, Burbank M. Bacillus and other spore-forming genera: variations in responses and mechanisms for survival. Annu Rev Food Sci Technol. 2015;6:351-69.

3. Joung KB, Cote JC. Evaluation of ribosomal RNA gene restriction patterns for the classification of Bacillus species and related genera. J Appl Microbiol. 2002;92:97-108.

4. Kovács E, Wirth R, Maróti G, Bagi Z, Nagy K, Minárovits J, Rákhely G, Kovács $\mathrm{KL}$. Augmented biogas production from protein-rich substrates and associated metagenomic changes. Bioresour Technol. 2015;178:254-61.

5. Ziganshin AM, Ziganshina EE, Kleinsteuber S, Nikolausz M. Comparative analysis of methanogenic communities in different laboratory-scale anaerobic digesters. Archaea. 2016;2016:3401272.
6. Ziganshina EE, lbragimov EM, Vankov PY, Miluykov VA, Ziganshin AM. Comparison of anaerobic digestion strategies of nitrogen-rich substrates: performance of anaerobic reactors and microbial community diversity. Waste Manag. 2017;59:160-71.

7. Newcombe DA, Schuerger AC, Benardini JN, Dickinson D, Tanner R, Venkateswaran K. Survival of spacecraft-associated microorganisms under simulated Martian UV irradiation. Appl Environ Microbiol. 2005;71:8147-56

8. Kempf MJ, Chen F, Kern R, Venkateswaran K. Recurrent isolation of hydrogen peroxide-resistant spores of Bacillus pumilus from a spacecraft assembly facility. Astrobiology. 2005;5:391-405.

9. Huang Q, Peng Y, Li X, Wang HF, Zhang YZ. Purification and characterization of an extracellular alkaline serine protease with dehairing function from Bacillus pumilus. Curr Microbiol. 2003;46:169-73.

10. Thomas L, Ushasree MV, Pandey A. An alkali-thermostable xylanase from Bacillus pumilus functionally expressed in Kluyveromyces lactis and evaluation of its deinking efficiency. Bioresour Technol. 2014;165:309-13.

11. Ouoba LI, Diawara B, Jespersen L, Jakobsen M. Antimicrobial activity of Bacillus subtilis and Bacillus pumilus during the fermentation of African locust bean (Parkia biglobosa) for Soumbala production. J Appl Microbiol. 2007;102:963-70

12. Hafeez FY, Yasmin S, Ariani D, Mehboob-ur-Rahman Zafar Y, Malik KA. Plant growth promoting bacteria as biofertilizer. Agron Sustain Dev. 2006;26:143-50.

13. Saranya P, Kumari HS, Rao BP, Sekaran G. Lipase production from a novel thermo-tolerant and extreme acidophile Bacillus pumilus using palm oil as the substrate and treatment of palm oil-containing wastewater. Environ Sci Pollut. 2014;R21:3907-19.

14. Meyers PR, Rawlings DE, Woods DR, Lindsey GG. Isolation and characterization of a cyanide dihydratase from Bacillus pumilus $\mathrm{C1}$. J Bacteriol. 1993;175:6105-12.

15. Rabah AB, Baki AS, Hassan LG, Musa M, Ibrahim AD. Production of biogas using abattoir waste at different retention time. Sci World J. 2010;5:23-6.

16. Mohammed WS, Ziganshina EE, Shagimardanova El, Gogoleva NE, Ziganshin AM. Draft genome sequence of Paenibacillus sp. EZ-K15 isolated from wastewater systems. BMC Res Notes. 2017;10:734.

17. Zerbino DR. Using the Velvet de novo assembler for short-read sequencing technologies. Curr Protoc Bioinform. 2010;11(11):5.

18. Rissman Al, Mau B, Biehl BS, Darling AE, Glasner JD, Perna NT. Reordering contigs of draft genomes using the Mauve aligner. Bioinformatics. 2009;25:2071-3.

19. Aziz RK, Bartels D, Best AA, DeJongh M, Disz T, Edwards RA, et al. The RAST server: rapid annotations using subsystems technology. BMC Genomics. 2008;9:75.

20. Lagesen K, Hallin P, Rødland EA, Staerfeldt HH, Rognes T, Ussery DW. RNAmmer: consistent and rapid annotation of ribosomal RNA genes. Nucleic Acids Res. 2007;35:3100-8.

21. Lowe TM, Eddy SR. tRNA scan-SE: a program for improved detection of transfer RNA genes in genomic sequence. Nucleic Acids Res. 1997;25:955-64.

Ready to submit your research? Choose BMC and benefit from:

- fast, convenient online submission

- thorough peer review by experienced researchers in your field

- rapid publication on acceptance

- support for research data, including large and complex data types

- gold Open Access which fosters wider collaboration and increased citations

- maximum visibility for your research: over $100 \mathrm{M}$ website views per year

At BMC, research is always in progress.

Learn more biomedcentral.com/submissions 